Meta

Journal des traducteurs

Translators' Journal

\title{
Comment on Sharma
}

\section{Daniel Slote}

Volume 39, numéro 2, juin 1994

La traduction vue de l'extérieur - Translation: a view from the outside

URI : https://id.erudit.org/iderudit/004183ar

DOI : https://doi.org/10.7202/004183ar

Aller au sommaire du numéro

Éditeur(s)

Les Presses de l'Université de Montréal

ISSN

0026-0452 (imprimé)

1492-1421 (numérique)

Découvrir la revue

Citer cet article

Slote, D. (1994). Comment on Sharma. Meta, 39(2), 313-315

https://doi.org/10.7202/004183ar

\section{Résumé de l'article}

Appliquée au texte de Arvind Sharma, la notion d'équivalence se révèle ténue, voire périlleuse. En effet, le concept de dharma dont il est question ici n'a pas d'équivalence lexicale dans une autre langue. Il s'ensuit que la traduction du mot dharma risque de poser un problème sérieux si l'on cherche à tout prix, comme c'est ici le cas, à traduire ce concept complexe par un terme " équivalent " simple en anglais. 


\title{
COMMENT ON SHARMA
}

\author{
DANIEL SLOTE
}

Université de Montréal, Montreal, Canada

\section{Résumé}

Appliquée au texte de Arvind Sharma, la notion d'équivalence se révèle ténue, voire périlleuse. En effet, le concept de dharma dont il est question ici n'a pas d'équivalence lexicale dans une autre langue. Il s'ensuit que la traduction du mot dharma risque de poser un problème sérieux si l'on cherche à tout prix, comme c'est ici le cas, à traduire ce concept complexe par un terme «équivalent» simple en anglais.

My gloss on Arvind Sharma's interesting article can be placed under the title Non verbum e verbo, sed sensum exprimere de sensu coined by Saint Jerome and which in itself is a gloss of Cicero's remarks to the effect that one should translate not the orator's text but the orator himself, i.e. the individual, highly relative meaning of a text in a given time and place.

The author's concern with semantic equivalence in the context of cross-cultural translations and the implications on the cultural level of insisting on lexical equivalence is a justifiable one. My own concern, however, has to do with the word insisting in his premise. The problem here is not with Mr. Sharma's analysis, which is sound; it lies in the approach the translators have adopted towards the original texts and their apparent insistence on purely verbal solutions with little if any attempt being made to bridge the cultural gap and the complexities that created it.

I think it is fairly safe to assume, now that Jakobson's rather weak defence of the adequacy of purely verbal explanations (1966) is no longer convincing as a building block in translation theory, that translatability is a relative and not an absolute notion. Pedersen (1979) maintains, as I do, that a text is translatable insofar as the translator can produce a text of his own which may not be semantically identical with the original, but one which is semantically equivalent to it. But equivalence, dynamic or otherwise, is a far from rigorously defined concept.

Modern translation theory has made much of the latter notion. The issue is particularly complex when translating abstractions, as is the case in Sharma's article. As Pedersen suggests, the only way for translations of abstract notions to be successful is to familiarize the readers of the translation with the social and cultural background of the source language. I might add, in the case of Bolle's translation of the Bhagavadgit $\bar{a}$, the same holds true for the translator himself who must become familiar with the complex spectrum, cultural, linguistic, and religious, that exists in translating a text of this density. And yet, neither Bolle nor the other translators mentioned by Sharma opt for an intralingual paraphrase of the more abstruse terms in their translations as a possible means of transmitting these complexities. Is this because of the frequently awkward solutions this technique entails ${ }^{1}$ ?

The moment we mention equivalence, we are looking at a given translation from the point of view of relevance (Catford 1965). The point is made that it is not fair to ask more of translation than what is demanded from monolingual communication, i.e., functional adequacy. The etymological terms given for the English word religion (to bind, to study, to pay attention) indicate a background to the term which is not too far removed from the background to the term dharma. Background since, as we move closer to the 
foreground of the word, the equivalence factor grows weaker and the loss incurred in rendering dharma by religion grows deeper. The insisting on lexical equivalence is at fault here, as Sharma suspects. My quarrel is with the translators, who in this instance slavishly produced a word-for-word translation which, as Sharma correctly states, can "lead to not merely curious but sometimes serious consequences". The lack of one-to-one correspondence between the notions of two vocabularies is a common difficulty in literary translation; the case in point here, where abstractions and concepts are the core of the problem, the resorting to circumlocution, although sometimes tedious, could have been attempted to suggest in English that which is contained in Sanskrit.

Another aspect of the problem of equivalence as applied to the texts Mr. Sharma brings to our attention, is the question of the receptor of the translated message. Nida and Taber (1969) make the interesting point that religious texts, because of their complexity and abstraction, lend themselves to multiple translation, e.g. one for scholars (and here I am paraphrasing to fit the text under discussion) who are steeped in the philosophical and religious notions of the two languages; another translation for the ordinary reader involving some paraphrasing; and perhaps a third one for the uneducated reader or the child involving much paraphrasing and adaptation. The idea, in very specific cases, is not so far-fetched as it may seem at first glance? 2 .

Matthew Arnold was of the opinion that the best test of a translation was "a competent scholar's judgment whether the translation more or less reproduces the effect of the original ${ }^{3}$." But who is this competent scholar? The same mysterious person Catford calls his competent informant? Or is Riffaterre's equally elusive archilecteur present here in different guise? The fact is that the function of these competent supermen has never been clearly defined by any of their creators and the bottom line we can draw under all of them is that textual equivalence, like formal correspondence, is a relative, approximate phenomenon. Perfect equivalence is an illusion in the same way the word religion or the norm as a perfect equivalent of dharma is an illusion. The notion that content can be extracted in toto from an original text during the translation process is an unfortunate mirage that the translators under discussion have taken for fact. Savory $(1957 ; 1969)$ is very direct in this regard when he states the translator must analyze his audience and translate accordingly. And we should remember Mounin's dictum "la communication par la traduction n'est... jamais vraiment finie". The whole notion of equivalence as proposed by Nida and others rests on shaky ground probably because of the strong dose of subjectivity involved in the elaboration of the concept.

When, as here, a concept (dharma) is to be translated, and as Sharma has pointed out in his criticism of the word-for-word approach, a religious concept that is often obscure to the culture that engendered it, equivalence - if there is any - is tenuous at best. Many translators, consciously or not, adopt a Saussurian model when translating, i.e. concept and word being two sides of the same coin. But when cultures and religions differ so markedly as in the case in point here, the translators should have approached the problem - just for the sake of convenience, if nothing else - as though each bilingual concept can have two or more reasonably synonymous terms to represent it. After all, if one is honest about the ultimate value of a translation, one must concur that it lies in its power to communicate and persuade. Any working translation theory that does not take into account the need for a reasonably objective basis for translation criticism as the basis for analysis of the source text is not functionally sound.

To sum up: this gloss, that started as a criticism of a criticism, has evolved into a critique of the notion of equivalence. This is logical I think, given the particular problem Sharma discusses in his paper. The attempts by the translators to render dharma by duty, law, traditional rules, etc. are misguided when the solution is obvious and simple: the 
term dharma should have been kept in English. And we might add, along with CarneRosse (1961), that the translation of any text must be dependent on the communication situation, i.e. on the aims and on the target group of the translated version. In other words, and in this specific case, let the translator pluck the term dharma from the original with all its attendant complexity intact and let it stand in the translated text as the equivalent of itself, even if this procedure entails paraphrasing or footnotes to get across the density of the notion to the reader.

Notes

1. Fitzgerald's translation of the Rubaiyat comes to mind. In a sense, his text is an intralingual paraphrase of the original, done partly to explain or render familiar certain cultural notions which Victorian readers even most of the highly educated ones - would have found tenuous.

2. I am reminded here of a remark I made concerning the difficulty of translating Rimbaud's Illuminations (Slote 1978):

Dévotion can give rise to at least ten (different) versions, all of which, translated on different levels, could be read like some poetic palimpsest until the English reader gets the same multiple messages as in the original creative process.

3. Matthew Arnold in Last Words, 1862.

\section{REFERENCES}

ARNOLD, M. (1905): On Translating Homer \& Last Words (1861-62), London.

CARNE-ROSSE, D. S. (1961): "Translation and Transposition" in Arrowsmith, W. and R. Shattuck.

CATFORD, J. C. (1965): A Linguistic Theory of Translation, Oxford.

HARRIS, Z. (1952): "Discourse Analysis", in Language, 28, 1-30.

JAKOBSON, R. (1966): "On Linguistic Aspects of Translation" in Brower, 32-39.

MOUNIN, G. (1963): Les problèmes théoriques de la traduction, Paris.

NIEWMARK, P. (1981): Approaches to Translation, Oxford.

NIDA, E. A. (1966): "Principles of Translation", (1959), in Brower, 11-31.

NIDA, E. A. (1964): Toward a Science of Translating, Leiden.

NIDA, E. A. and C. R. TABER (1969): The Theory and Practice of Translation, Leiden.

OGDEN, C. K. and I. A. RICHARDS (1969): The Meaning of Meaning, (1953), 10th edition, London.

PEDERSEN, V. H. (1979): "Linguistic Relativity and Translation Theory", in Publications of the Department of English 8, University of Copenhagen, 88-103.

SAVORY, T. (1969): The Art of Translation, (1957; 2nd ed, 1968), London.

SLOTE, D. (1978): “Translating Rimbaud's Illuminations: Games with Words" in Meta, vol. 23, No 1, 86-97, Montréal, Presses de l'Université de Montréal.

WHORF, B. L. (1967): "Language, Thought, and Reality", J. B. Carroll (Ed.), Selected Writings of B. L. Whorf (1956), Cambridge, Mass. 